\title{
O ator e a supermarionete (versão integral)
}

Edward Gordon Craig

Tradução: Almir Ribeiro

Dedicado com todo afeto a meus bons amigos De Vos e Alexander Hevesi.

"Para salvar o Teatro, o Teatro precisa ser destruído, os atores e atrizes precisam todos morrer de peste... Eles tornam a Arte impossível". - Eleonora Duse: Studies in Seven Arts, Arthur Symons (Constable, 1900)

Sempre foi um tema para discussões a questão se atuar é uma arte ou não e, logo, se o ator é um artista ou algo bem diferente. Muito pouco existe que possa indicar que esta questão tenha preocupado as mentes dos principais pensadores ao longo da história, mas existem evidências suficientes que comprovam que se eles tivessem decidido considerar este tema de maneira frontal, teriam aplicado a ele o mesmo método de investigação utilizado ao se examinar as artes da Música e Poesia, da Arquitetura, Escultura e Pintura.

Por outro lado, muitos debates calorosos ocorreram em certos círculos sobre esse mesmo tópico. Os que tomam parte neles, raramente são atores, muito ocasionalmente são sequer pessoas de Teatro, e todos demonstram muita exaltação irracional e pouco conhecimento sobre o assunto. Os argumentos contra a atuação ser uma arte e contra o ator ser um artista são geralmente tão pouco razoáveis e tão pessoais em sua aversão ao ator, que provavelmente seja esta a explicação pela qual os atores nunca tenham se dado ao trabalho de entrar no debate. Regularmente, a cada nova temporada, surge um novo ataque trimestral ao ator e a essa sua extraordinária vocação. 0 ataque normalmente termina com a retirada do inimigo. Em geral, são literatos e intelectuais que compõem a tropa inimiga. Sob o pretexto de terem assistido a peças por

\footnotetext{
${ }^{1}$ Almir Ribeiro é diretor teatral, pedagogo, mestre em Artes Visuais pela UFRJ, doutorando em Artes Cênicas pela USP e autor do livro Kathakali: uma introdução ao Teatro e ao sagrado da Índia.
} 
toda a vida ou sob o pretexto de nunca terem assistido a uma peça sequer em toda a vida, eles criam ataques por alguma razão que talvez somente eles possam saber. Tenho acompanhado esses ataques regularmente, temporada após temporada, e eles parecem ser movidos pela irritabilidade, por inimizades pessoais ou por simples arrogância. São irracionais do começo ao fim. Não se pode fazer tais ataques ao ator ou à sua vocação. Minha intenção aqui não é me unir a essas tentativas, mas simplesmente apresentar o que me parece ser a sequência lógica dos fatos de um caso curioso, e acredito que tais fatos não admitem qualquer tipo de questionamento.

Atuar não é uma arte. É, portanto, incorreto se falar do ator como um artista. Pois o acidental é um inimigo do artista. A arte é a antítese absoluta do caos, e o caos é criado por um amontoamento de vários acidentes. A arte se atinge unicamente de propósito. Portanto, fica claro que para se produzir qualquer obra de arte podemos trabalhar apenas sobre aqueles materiais que somos capazes de controlar. O homem não é um desses materiais.

A própria natureza do homem tende na direção da liberdade. Ele, portanto, carrega em si mesmo a prova de que, enquanto material para o Teatro, o homem é inútil. No teatro moderno, uma vez que se utiliza de corpos de homens e mulheres como seu material, tudo o que é apresentado ali é de natureza acidental. As ações do corpo do ator, as expressões de seu rosto, os sons de sua voz, tudo fica a mercê dos ventos de suas emoções. Esses ventos que habitualmente sopram ao redor de todo artista é o que os move, mas não lhes tira, no entanto, o equilíbrio. Com o ator, todavia, ele é possuído pela emoção, apodera-se de seus membros, movendo-os à revelia de sua vontade. Ele fica completamente subordinado a ela, se movendo como alguém em um sonho frenético ou transtornado, balançando pra lá e pra cá. Sua cabeça, seus braços, seus pés, quando não estão sob controle, se tornam tão frágeis para resistir contra a torrente de suas paixões, que podem traí-lo a qualquer momento. E é inútil tentar argumentar consigo mesmo. As sensatas orientações de Hamlet (aliás, as do sonhador, não as orientações do lógico) são jogadas ao vento. À medida que as suas emoções se acaloram, seus membros se recusam, e se recusam de novo, a obedecer a sua mente. Enquanto isso, a mente está continuamente criando aquele calor que colocará essas emoções em chamas. O que falamos sobre os movimentos, o mesmo é válido para as expressões de sua face. Se por acaso, essa mente em luta, consegue por um momento mover os olhos, ou os músculos da face, em uma direção desejada - quando consegue 
arduamente submeter a face por um pequeno instante sob seu comando - ela é subitamente varrida pela emoção, que se aqueceu a partir da ação da própria mente. Instantaneamente, como um relâmpago, e antes que a mente tenha tempo de gritar e reclamar, o calor da paixão tomou conta da expressão do ator. Ela se altera e muda, oscila e desvia, é perseguida pela emoção desde a fronte do ator, entre seus olhos, até a sua boca. Agora ele se encontra completamente à mercê da emoção e gritando para ela: "Faça de mim o que quiser!" Sua expressão fora de controle vaga desvairada de um lugar a outro. Enfim: "Nada surge de nada". Acontece com a voz o mesmo que com os movimentos. A emoção quebra a voz do ator. Ela agita a voz para que se junte a essa conspiração contra a mente. A emoção atua sobre a voz do ator de tal forma que ele pode acabar produzindo a impressão de uma emoção absolutamente divergente. Não há utilidade em afirmar que a emoção é o espírito dos deuses, e que é isso precisamente o que o artista almeja produzir. Primeiramente porque isso não é verdade e ainda que fosse verdade, uma emoção esporádica, um sentimento casual, não pode ter valor artístico algum. Portanto, como vemos, a mente do ator é menos potente que sua emoção, pois a emoção é capaz de subjugar a mente para ajudá-la na destruição daquilo que a mente produziria. E como a mente se encontra escravizada pela emoção, a consequência é que acidentes sobre acidentes continuam ocorrendo. Logo, chegamos a esta conclusão: que a emoção é, a princípio, a causa que cria e que, em seguida, destrói. A arte, como dissemos, não pode admitir o acaso. Por isso, o que o ator nos oferece não é uma obra de arte, é uma série de confissões acidentais. No início o corpo humano não era utilizado como material para a Arte do Teatro. No início as emoções de homens e mulheres não eram consideradas como algo adequado a ser exibido em público. Um elefante e um tigre em uma arena agradavam mais ao gosto, quando o objetivo era excitar o público. A impetuosa luta entre o elefante e o tigre nos oferece toda a excitação que se pode ter no Teatro moderno, e de uma forma genuína. Tal exibição, no fundo, não é brutal, é sim delicada e humana, pois não há nada mais ultrajante que aqueles homens e mulheres soltos sobre uma plataforma, para que possam exibir aquilo que verdadeiros artistas se recusariam a mostrar, exceto veladamente, sob uma forma que suas mentes engendrassem. Como aconteceu que o homem tenha sido persuadido a tomar o lugar que até aquele momento era ocupado por animais não é difícil de conjecturar.

O homem de maior conhecimento se encontra com o homem de maior temperamento. Ele se dirige ao outro de uma maneira mais ou menos como se segue: "Você 
possui uma compostura soberba, que modos magníficos de se movimentar! Sua voz é como o cantar dos pássaros, e que brilho em seus olhos! Que nobreza em suas expressões! Você quase se assemelha a um deus! Seguramente as pessoas ao vê-lo devem comentar entre elas esta nítida maravilha que transparece em você. Eu proponho escrever algumas palavras com as quais você se dirigirá às pessoas. Você se colocará diante delas e dirá essas minhas palavras, da maneira que lhe convier, e tenho absoluta certeza que será perfeito."

E o homem de temperamento responderá: "Verdade? Tenho mesmo para você a aparência de um deus? É a primeira vez que eu sequer penso sobre isso. E você acha que aparecendo diante das pessoas eu poderia criar uma impressão que pudesse agradar a eles, e causar-lhes entusiasmo?" "Não, não, não" diz o homem inteligente "de maneira alguma somente em aparecer, mas se você tivesse alguma coisa para dizer você criaria, sem dúvida, uma forte impressão".

O outro responde: "Eu acho que eu teria alguma dificuldade em falar suas palavras. Seria mais fácil se eu simplesmente aparecesse e dissesse alguma coisa instintivamente, assim como 'Saudações a todos!' Eu sinto que talvez fosse capaz de ser mais eu mesmo se eu agisse dessa forma" "Esta é uma idéia excelente", responde o tentador, "essa sua idéia: 'Saudações a todos!' Exatamente sobre esse tema eu escreverei, digamos, umas cem ou duzentas linhas, e você será a pessoa exata para falar esse texto, já que é um tema que você mesmo sugeriu: 'Saudações!'. Está combinado então que você fará isso?" "Se assim o quer,' retruca o outro, com a boa vontade vazia de razão, e a vaidade derramando pelas bordas.

E assim a comédia do autor e do ator começa. O jovem aparece diante da multidão e diz o seu texto, e o falar do texto se revela uma esplêndida propaganda da arte da literatura. Depois dos aplausos o jovem é rapidamente esquecido, eles até mesmo o perdoam pela maneira que disse o texto; mas como era uma idéia inovadora e original em seu tempo, o autor julgou-a valiosa, e depois de um curto tempo outros autores também julgaram ser uma excelente idéia utilizar homens belos e cheios de entusiasmo como instrumentos. Não importa que esse instrumento seja um ser humano. Ainda que não saibam exatamente como utilizar o instrumento, eles conseguem tocá-lo, ainda que de maneira rude, e lhe são úteis. Hoje temos o estranho panorama de um homem satisfeito em passar adiante as idéias de outro, às quais esse outro deu forma, enquanto ao mesmo tempo ele exibe sua pessoa para um público. Ele faz isso porque se sente lisonjeado, e a vaidade é destituída 
de razão. Mas a cada momento, e não importando o quanto esse mundo possa durar, a natureza no homem irá lutar por liberdade e se rebelará contra ser feita escrava ou meio para a expressão das idéias de outro. A coisa toda é um assunto bastante sério, e não é bom que o coloquemos de lado, protestando que o ator não é simplesmente um meio para o pensamento de um outro, mas que ele investe de vida as palavras mortas de um autor. Porque ainda que isso fosse verdade (o que não é), ainda que o ator estivesse ali apresentando suas próprias idéias que ele mesmo compôs, sua natureza ainda assim estaria servil, seu corpo teria que estar escravizado por sua mente, e isso, como demonstrei, é o que um corpo saudável se recusa terminantemente a ser. Portanto, o corpo humano, pelas razões que apresentei, é por natureza terminantemente inútil como material para uma arte. Eu estou absolutamente consciente do sentido radical desta afirmação, e como isso atinge a homens e mulheres de nossos dias, como também a uma classe que merece ser amada, por isso me explico melhor para que não ofenda alguém de maneira não intencional. Eu sei perfeitamente bem que o que disse aqui não criará um êxodo de todos os atores do mundo, levando-os a refugiarem-se em sombrios monastérios onde passarão o resto de suas vidas rindo, tendo a arte do Teatro como assunto principal para divertidas conversas. Como escrevi anteriormente, o Teatro continuará a crescer e os atores continuarão por vários anos estorvando seu desenvolvimento. Mas eu vejo uma fresta através da qual, a seu tempo, os atores poderão escapar da escravidão em que se encontram: Eles devem criar para si uma nova forma de atuar, que se componha fundamentalmente de gestos simbólicos. Hoje eles imitam e interpretam, amanhã eles deverão representar e interpretar e no terceiro dia eles deverão criar. Assim, o estilo retornará. Hoje o ator imita um certo ser. Ele grita para a audiência: "Olhem-me, eu estou agora fazendo de conta que sou fulano ou sicrano, e estou fazendo de conta que faço isso ou aquilo!." E ele segue em frente imitando o mais precisamente possível aquilo que ele anunciou que iria indicar. Por exemplo, ele é Romeu. Ele diz à audiência que ele está amando, e ele começa então a mostrar isso beijando Julieta. Isto, afirmam, é uma obra de arte. E afirmam ser esta uma forma inteligente de sugerir uma idéia. Isso é como se um pintor desenhasse em uma parede a figura de um animal com longas orelhas e depois escrevesse abaixo dele: "isto é um burro". Qualquer um poderia pensar que as orelhas compridas do animal já o teria deixado suficientemente explícito, mesmo sem a inscrição, e que qualquer criança de dez anos faria o mesmo. A diferença entre a criança de dez anos e o artista é que o artista é 
aquele que desenhando certos sinais e formas cria a impressão de um burro. E o maior artista é aquele que cria a impressão de toda a espécie de burros, o espírito da coisa.

O ator olha para a vida como uma máquina fotográfica olha para a vida, e o que ele almeja é fazer uma imagem que rivalize com a fotografia. Ele nunca sequer sonha com sua arte sendo uma arte como, por exemplo, a música. Ele tenta reproduzir a Natureza, raramente pensa em inventar com o auxílio da natureza, e nunca sonha em criar. Como eu disse, o melhor que ele faz quando quer capturar e oferecer a poesia de um beijo, o calor de uma luta, ou a calma da morte, é copiar servilmente, fotograficamente: ele beija, ele luta, ele deita e imita morrer. Quando se para para pensar sobre isso, não é tudo incrivelmente estúpido? Não é uma arte pobre e uma inteligência pobre a que não consegue oferecer o espírito e essência de uma idéia para uma audiência, mas somente mostrar uma cópia desprovida de arte, um fac-símile da coisa em si? Isto é para um imitador, não um artista. Isto é reclamar parentesco com um ventríloquo. ${ }^{2}$

Existe uma expressão de palco usada por atores: "entrar na pele do papel." Uma melhor ainda seria "sair da pele do papel, de uma vez por todas". "O quê?" grita o ator com o sangue a ferver e os olhos faiscantes. "Não existirá carne e sangue nessa sua arte do teatro? Não haverá vida?" Isso depende o que você chama de vida, signor, quando você usa essa palavra em relação à arte. O pintor quando fala sobre vida em sua arte se refere a algo bastante diferente, e os outros artistas geralmente se referem a algo essencialmente espiritual. Somente o ator, o ventríloquo, ou o taxidermista são os que, ao falar sobre colocar vida em seus trabalhos, querem dizer uma reprodução imitativa da vida, algo ostensivo em sua aparência, e por essa razão eu digo que seria melhor se o ator saísse da pele do personagem de uma vez por todas. Se existir algum ator lendo isso, não existiria, por acaso, alguma maneira pela qual eu poderia fazê-lo se dar conta do absurdo ridículo dessa sua ilusão, dessa crença que se deve almejar realizar uma cópia, uma reprodução do que é real? Suponhamos então, que tal ator

\footnotetext{
2 "Portanto, quando um desses homens capazes, por sua habilidade, de imitar a qualquer coisa, vem até nós e se propõe a exibir a ele mesmo e a sua poesia, prostramo-nos diante dele e o saudamos como um ser especial e sagrado; mas precisamos também informá-lo que em nossa cidade não é permitido que existam pessoas como ele: a lei assim o impede. Então, depois de termos vertido mirra sobre sua cabeça e o coroado com fitas de lã, o mandaremos embora para outra cidade qualquer. Pois para nós, para o bem estar de nossa alma, recorremos somente aos poetas e narradores mais austeros e severos que imite para nós o homem de bem e se adeque em sua linguagem aos modelos estabelecidos desde o início, quando começamos a educar nossos guerreiros." Platão. (A passagem completa, sendo longa demais para ser impressa aqui, indicamos ao leitor A República, Livro III, p. 395). (N. do A.)
} 
está aqui comigo enquanto falo; e convidarei um músico e um pintor para se juntar a nós. Deixemo-los falar. Já falei o bastante até aqui para fazer parecer que estou constantemente depreciando o trabalho do ator por motivos triviais. Tenho falado dessa maneira por causa do meu amor ao Teatro, e de minha esperança e crença que em breve um desenvolvimento extraordinário surgirá e reanimará o que se mostra falho no Teatro, e de minha esperança e crença que o ator aportará a força de sua coragem para ajudar nesse renascimento. Minha posição sobre o assunto é mal interpretada por muitos no meio teatral. Considera-se que seja minha posição, somente minha; devo parecer a muitos olhos um dissidente brigão, um pessimista, rabugento; alguém que se cansou de alguma coisa e decidiu agora destruí-la. Portanto, deixemos os outros artistas falarem com o ator, e deixemos que o ator se defenda o melhor que puder, e deixemos que escute as opiniões dos outros sobre a arte. Sentemos aqui conversando, o ator, o músico, o pintor e eu. Eu, que represento uma arte distinta de todas essas, permanecerei em silêncio.

Ao sentarmo-nos aqui, a conversa se encaminha em direção à Natureza. Estamos rodeados por belos e sinuosos montes e pelas árvores, enormes e altíssimas montanhas ao longe, cobertas de neve e em torno de nós, inúmeros e delicados sons da Natureza inspiradora - Vida! "Como é belo", diz o pintor, "que bela a sensação de tudo isso!" Ele sonha com a quase impossibilidade de converter em sua tela toda a riqueza terrena e espiritual que está ao seu redor, mesmo assim, ele encara isso da maneira que os homens geralmente encaram, e que é a mais perigosa. $O$ músico fita o chão. $O$ fitar do ator é direcionado para dentro de si. Ele inconscientemente desfruta a sensação de si próprio, como se representasse o papel principal em uma cena realmente estupenda. Ele caminha através do espaço entre nós e a paisagem, cruzando em semicírculo, ele admira o magnífico panorama sem enxergá-lo, consciente apenas de si mesmo e de sua atitude. Obviamente uma atriz estaria ali humilde na presença da Natureza. Ela é apenas uma pequenina coisa, um pequeno e pitoresco átomo, pois pitoresca sabemos que ela é a todo momento, através do suspiro com o qual, quase inaudível por todos, ela transmite a sua audiência e a si mesma, que ela está ali, "pobre de mim", na presença do Deus que fez a ela e a todo o resto das baboseiras sentimentais. Então, reunidos aqui, cada um com a atitude que lhe é natural, prossigamos a nos questionar uns aos outros. E vamos imaginar que, pelo menos uma vez, estejamos todos realmente interessados em descobrir tudo sobre o interesse dos 
outros, e do trabalho dos outros. (Eu garanto que isso é muito incomum, pois o egoísmo intelectual, a mais alta forma de estupidez, aprisiona muitos artistas em um cruel e diminuto cercado). Mas, tomemos isso como certo, que existe um interesse geral, que o ator e o músico desejam aprender algo sobre a arte da pintura; e que o pintor e o músico desejam compreender do ator no que consiste o seu trabalho e por que, e se ele a considera uma arte. Aqui eles não devem medir consequências e falar o que cada um acredita. Como estão à procura da verdade, eles não têm nada a temer; são todos bons companheiros, todos bons amigos, e nem possuem as peles tão frágeis que não resistam tomar alguns golpes. "Diga-nos", pergunta o pintor, "é verdade que antes de você atuar devidamente em um papel você deve sentir as emoções do personagem que você está representando?" "Bem, sim e não, depende do que você quer dizer" respondeu o ator. "Nós devemos primeiramente estar disponíveis para sentir e compartilhar, mas também criticar as emoções do personagem. Olhamos para ele de uma certa distância antes de nos aproximarmos. Coletamos o máximo que podemos do texto e procuramos lembrar de todas as emoções adequadas para ser exibida por este personagem. Depois de ter muitas vezes rearranjado e selecionado as emoções que consideramos importantes, nós então treinamos reproduzi-las diante da audiência; e para isso precisamos sentir o mínimo possível; de fato quanto menos sentirmos, mais seguro será nosso controle sobre nossa expressão facial e corporal". Com um gesto de cordial impaciência, o artista se levanta e caminha indo e vindo. Ele esperava que seu amigo dissesse que isso não tem nada a ver de maneira alguma com emoções, e que ele pudesse controlar sua face, feições, voz e tudo, exatamente como seu, se corpo fosse um instrumento. Enquanto isso, o músico afunda ainda mais em sua cadeira. "Mas, nunca houve um ator", pergunta o artista, "que tenha treinado seu corpo da cabeça aos pés, que pudesse responder à atividade de sua mente sem permitir que as emoções sejam sequer despertadas? Seguramente deve existir um ator, digamos um em dez milhões, que tenha conseguido isso?" "Não," diz o ator enfático, "nunca, nunca; nunca houve um ator que tenha atingido tal estado de perfeição mecânica, onde seu corpo fosse completamente escravo de sua mente. Edmund Kean na Inglaterra, Salvini na Itália, Rachel, Eleonora Duse, todos eles me vêm à mente, mas eu repito que nunca houve um ator ou atriz como você descreveu". O artista então pergunta: “Logo você admite que exista um estado de perfeição?” "Mas é claro! Mas é impossível; e será sempre impossível,' brada o ator; e ele se levanta - quase com uma 
sensação de alívio. "Isto é o mesmo que dizer, que nunca tenha existido um ator perfeito, nunca tenha havido um ator que não tenha arruinado sua performance uma, duas, dez vezes, quem sabe cem vezes, durante uma noite? Nunca existiu um trecho de uma atuação que pudesse ser definida como quase perfeita, e que nunca existirá?" Como resposta, o ator pergunta rapidamente: "Mas existiu alguma vez uma pintura, ou peça arquitetônica, ou uma peça musical que pudesse ser definida como perfeita?" "Sem dúvida", eles responderam. "As leis que controlam nossas artes fazem isto ser possível." "Uma pintura, por exemplo," continua o artista, "pode consistir-se de quatro linhas, ou quatrocentas linhas, dispostas em posições definidas. Ela pode ser a mais simples possível e ainda assim ser perfeita. Primeiramente, eu posso escolher com o quê serão feitas as linhas, depois escolher onde eu colocarei as linhas. Eu posso ponderar sobre isso o tanto que eu achar necessário, eu posso alterá-lo, e depois, em um estado livre de qualquer excitação, precipitação, preocupação, nervosismo - de fato, sob qualquer estado eu posso fazer escolhas (assim como, obviamente, preparo, espera e seleção) - eu posso dispor todas as linhas e, ei-las agora, todas em seus devidos lugares. Possuindo os materiais necessários, nada exceto minha própria vontade pode mover ou alterar o trabalho e, como eu disse, minha própria vontade está inteiramente sob meu controle. A linha pode ser reta ou se curvar, e pode se arredondar se eu assim desejar. Não existe o temor de que quando eu desejar fazer uma linha reta eu venha a fazer uma curva ou quando eu queira fazer uma linha curva, que surjam partes de um quadrado nela. E quando a obra estiver pronta - terminada - não ficará submetida a nenhum tipo de mudança a não ser aquelas que o Tempo, que terminará por destruí-la, determinar." "Isto é realmente uma coisa extraordinária", retruca o ator; "quem dera isso fosse possível em meu trabalho"' "Sim," responde o artista, "é realmente uma coisa extraordinária", e isto é que acredito que faça a diferença entre um resultado inteligente e um resultado fortuito ou casual. O resultado mais inteligente define a obra de arte. O resultado fortuito é uma obra do acaso. Quando o resultado inteligente atinge a forma mais alta possível ela se torna uma obra de arte refinada. Por isso, eu tenho afirmado constantemente, a não ser que esteja enganado, que seu trabalho não é de natureza artística. É como dizer (e você mesmo o disse) que todo resultado em seu trabalho está sujeito a qualquer mudança concebível que suas emoções possam causar. O que você concebe em sua mente, seu corpo não permite, por natureza, completar. Na verdade, seu corpo, vencendo o melhor de sua 
inteligência, em várias situações no palco, expulsou sua inteligência por completo. Alguns atores parecem dizer: 'Que valor existe em conceber belas idéias? Com que objetivos minha mente deveria conceber uma ótima idéia, uma ótima reflexão, para que meu corpo, tão fora do meu controle, acabe por estragá-la? Vou jogar minha mente ao mar e torcer que meu corpo resgate a mim e a peça ao mesmo tempo' Parece-me existir alguma sabedoria no ponto de vista de tal ator. Ele não vacila entre as duas coisas que estão contidas nele, uma contra a outra. Ele não tem nem um pouco de receio do resultado e o enfrenta como um homem, às vezes brincando como um centauro. Ele coloca de lado toda ciência, toda precaução, toda razão, e o resultado é o entusiasmo do público, que para isso não hesita em pagar, de boa vontade. Mas, estamos falando aqui de algo além do entusiasmo, e ainda que se aplauda o ator que exibe tal personalidade, ele é o que se aplaude, não o que está fazendo ou como está fazendo; e isso não tem nada que ver, de maneira alguma, com arte, absolutamente nada que ver com a arte, com calcular ou projetar". "Que gentil e amigável criatura você é," ri o ator alegremente, "dizendo a mim que minha arte não é arte! Mas eu acredito que entendo o que está dizendo. Você quer dizer que antes que eu apareça sobre o palco, e antes que meu corpo comece a entrar em questão, eu sou um artista". "Bem, sim, você é, por acaso você é, porque você é um ator muito ruim, você é péssimo no palco, mas tem idéias, você possui imaginação; você é mais uma exceção, devo dizer. Tenho ouvido você me contar como interpretaria Ricardo III, o que você faria, que atmosfera singular você infundiria em toda a obra. O que você me conta, você encontrou a partir do texto, e o que você inventou e adicionou a ele é tão notável e tão consequente em sua lógica, tão distinto e claro em sua forma que se você tivesse transformado seu corpo em uma máquina, ou em uma peça sem vida de algum tipo de material como a argila, e se ele pudesse obedecer a você a todo e cada momento pelo espaço completo de tempo que estivesse diante da audiência, e se pudesse colocar de lado a poesia de Shakespeare - então você seria capaz de realizar uma obra de arte daquilo que existe em você. Nesse caso você não teria somente sonhado, você teria realizado e com perfeição, e essa realização poderia ser repetida inúmeras vezes sem que houvesse diferenças maiores do que as existentes entre duas migaIhas"' "Ah," suspira o ator, "você me coloca diante de uma perspectiva terrível. Você quer provar a mim que é impossível para nós sequer pensarmos em ser artistas. Você nos tira nosso maior sonho e não nos oferece nada em troca"' "Não, não, eu não tenho que 
dar nada a vocês. É vocês quem devem encontrar. Seguramente existem leis nas raízes da Arte do Teatro, assim como existem leis nas raízes de todas as verdadeiras artes, as quais, se encontradas e dominadas levarão você até onde desejar." "Sim, o que esta busca levará os atores a encontrar é um muro." "Salte-o, então!" "É alto demais!" "Escale-o!" "Mas como saber aonde levará?" "Ora, para cima e além." "Isso são apenas palavras vagas, palavras ao vento." "Bem, essa é exatamente a direção que vocês colegas deveriam tomar; voar ao vento, viver ao vento. Alguma coisa se seguirá quando algum de vocês iniciar a fazê-lo. Eu suponho" ele continua, "que vocês chegarão à raiz da questão a seu tempo, e então, que esplêndido futuro se descortina adiante! De fato, eu o invejo. Eu não tenho certeza que eu não quisesse que a fotografia tivesse sido descoberta antes da pintura, para que nós, desta geração, pudéssemos ter a excitante alegria em avançar, demonstrando que a fotografia estava muito bem em seu caminho, mas que existe uma coisa ainda melhor!" "Você está afirmando que nosso trabalho está no mesmo nível da fotografia?" "Não, de modo algum, isso está longe de estar correto. Enquanto arte, ele está abaixo até mesmo da fotografia. Na verdade, você e eu estivemos conversando este tempo todo enquanto o músico esteve sentado quieto, afundando lentamente em sua cadeira. Mas, nossas artes ao lado da sua arte, são brincadeiras, jogos, absurdidades." Neste momento, o músico decide estragar tudo se levantando e emitindo uma observação absolutamente tola. $\mathrm{O}$ ator imediatamente exclama, "Eu não consigo ver nisso uma observação maravilhosa de ser feita por um representante da única arte do mundo", ao que todos riem - o músico de maneira constrangida e acanhada. "Meu caro colega, é só porque ele é um músico. Ele não é nada fora da sua música. Ele é, de certa forma, um tolo, exceto quanto fala através de notas, tons, e as outras coisas. Ele mal domina nosso idioma, ele mal conhece nosso mundo, e quanto maior o músico, mais isso fica nítido; na verdade é mau sinal quando você encontra um compositor que seja inteligente. E o músico atualmente quando é um intelectual, o que em si já é outra coisa - não citemos nomes aqui -, ele se torna popular. Que ator ele não teria se tornado! Que personalidade! Eu acredito que por toda a sua vida ele tenha ansiado por ser ator, e acredito que teria sido um excelente, uma vez que se tornou um músico - ou um dramaturgo? De qualquer maneira, se converteu em um grande sucesso - um sucesso da personalidade." "Por que não um sucesso da arte?" pergunta o músico. "Bem, a que arte você se refere?" "A todas as artes combinadas," ele responde desajeitado, mas tranquilo. "Como pode ser 
isto? Como pode todas as artes combinarem e constituírem uma única arte? Pode-se apenas constituir uma brincadeira - um Teatro. Apenas as coisas que, lentamente, através de leis naturais, se unem, possuem o direito, no curso de muitos anos ou séculos, de pedir à Natureza que as confiram um novo nome para suas realizações. Somente dessa forma uma nova arte pode nascer. Eu não acredito que nossa velha mãe dê sua aprovação a processos forçados, e se ela por um instante faz de conta que não vê, logo ela se vinga. O mesmo vale para as artes. Não se pode amalgamá-las e começar a bradar que se criou uma nova arte. Se você puder encontrar na Natureza um material novo, um que nunca tenha sido utilizado pelos homens para dar forma a suas idéias, então você pode dizer que está no caminho de criar uma nova arte. Pois então terá encontrado aquilo com o que poderá criá-la. Só resta a você começar. 0 Teatro, como você pode ver, ainda está por encontrar este material.” E assim esta conversa termina.

De minha parte eu concordo com a última afirmação do artista. Meu prazer não é competir com o mais esforçado dos fotógrafos. Eu quero sempre almejar obter algo inteiramente oposto à vida como a vemos. Essa vida cotidiana, adorável assim como é para todos nós, para mim não é algo que se deva pesquisar, ou devolver para o mundo, mesmo que sob alguma convenção. Eu penso que meu objetivo deveria ser acima de tudo capturar algum relance longínquo deste espírito que chamamos Morte, e resgatar as coisas belas do mundo imaginário. Dizem que são frias essas coisas mortas. Eu não sei, elas frequentemente parecem mais cálidas e mais vivas que essas que desfilam por aí como vivas. Sombras, espíritos, parecem a mim mais belos, e cheios de maior vitalidade que homens e mulheres. Cidades inteiras de homens e mulheres cheias de mesquinhez, criaturas inumanas, segredos, friezas geladas, humanidades embrutecidas. Pois, observando-se atentamente a vida, pode-se logicamente pensar que tudo isso se trata não do que é belo, nem do que é misterioso, nem do que é trágico, mas do estúpido, do melodramático e do tolo: uma conspiração contra a vitalidade, tanto quanto contra o entusiasmo e a paixão. E dessas coisas que carecem da luz da vida não é possível retirar inspiração. Mas dessa misteriosa, feliz e estupendamente completa vida que é chamada de Morte, essa vida de sombras e de formas desconhecidas, onde não pode tudo ser escuridão e névoa como se supõe, mas de uma cor vívida, uma luz vívida, de formas bem definidas; e onde se encontram pessoas de estranha figura, ferozes e solenes, figuras belas e figuras calmas. E essas 
figuras impelidas para algum tipo de maravilhosa harmonia de movimentos. Isso tudo é algo mais que uma mera questão de fato. A partir dessa idéia de Morte, que se assemelha a uma primavera, um florescer, desse território e dessa idéia, pode advir uma inspiração tão vasta que, exultante e sem hesitar, eu saltaria em direção a ela, e eis que, em um instante, eu encontraria meus braços repletos de flores. Eu avanço mais um passo ou dois e novamente a abundância me rodeia. Eu atravesso calmamente um mar de beleza, eu navego para onde o vento me levar. Lá, lá não há perigo. Isto seria o bastante para os meus desejos subjetivos, mas o Teatro do mundo não é representado por mim, nem por uma centena de artistas e atores, mas por algo muitíssimo diferente. Portanto, a natureza de meus anseios pessoais tem muito pouca importância. O objetivo do Teatro como um todo é a restauração de sua arte e ela deve começar por banir a idéia de imitação, esta idéia de reproduzir a natureza, pois enquanto a imitação existir no Teatro, o Teatro jamais será livre. Os atores devem ser treinados sob a influência de preceitos antigos (se os princípios mais ancestrais e refinados se mostrarem demasiadamente severos para se começar), e deverão evitar o desejo frenético de colocar vida em seus trabalhos, pois em apenas uma em cada mil oportunidades isso não significará a utilização de gestos excessivos, uma mímica acelerada, falas gritadas e cenários suntuosos sobre o palco, na precipitada e vã crença de que, através desses meios, a qualidade vida poderá ser invocada ali. Mas em algumas ocasiões, para confirmar a regra, isso por vezes, parcialmente acontece. E acontece, parcialmente apoiado na efervescência das personalidades do palco. É um caso de inegável triunfo apesar das regras, com desprezo pelas regras, e nós que assistimos, jogamos nossos chapéus para o alto e aplaudimos freneticamente. Somos obrigados a isso, sem questionar ou refletir; seguimos a correnteza entre admirados e sugestionados. $O$ fato de estarmos hipnotizados pouco nos importa: ficamos encantados por estarmos emocionados, e literalmente pulamos de alegria por isso. A grande personalidade triunfou sobre nós e sobre a arte. Mas personalidades como tal, são extremamente raras, e se queremos ver uma personalidade perseverar no Teatro e triunfar completamente como ator precisamos ser, ao mesmo tempo, indiferentes sobre a peça e sobre os outros atores, sobre a beleza e sobre a arte.

Aqueles que não concordam comigo nesse assunto são os veneradores, ou admiradores respeitosos das personalidades do palco. É intolerável a eles que eu diga que o Palco devesse ser limpo de todos seus atores e atrizes, para que possa novamente 
renascer. Como poderiam concordar comigo? Isso incluiria ter que remover os seus favoritos - os dois ou três seres que transformam o palco, segundo eles, de uma brincadeira em um país ideal. Mas o que, afinal, eles temem? Não existe perigo que ameace seus favoritos - pois se fosse possível instituir, à força, uma lei que proibisse a homens e mulheres de subirem ao palco de um teatro, isto não afetaria em nada os seus favoritos - esses homens e mulheres de personalidade a quem os frequentadores de teatro coroaram. Consideremos que algumas dessas personalidades tivessem nascido em um período em que o Palco não existisse; isso teria, de alguma maneira, diminuído seus prestígios, dificultado sua expressividade? Nem um pouco. Personalidades inventam seus meios e maneiras de se expressar; e atuar é apenas um - no mínimo - dos meios para as grandes personalidades, e esses homens e mulheres teriam sido famosos em qualquer tempo e em qualquer atividade. Mas, se é verdade que existam muitos para quem é intolerável que eu proponha que se limpe o Palco de TODOS os atores e atrizes para que a Arte do Teatro renasça, existem outros que concordam comigo.

"O artista," disse Flaubert, "deve se dedicar ao seu trabalho como Deus em sua criação, invisível e todo poderoso; ele deve ser pressentido em todos os lugares e visto em lugar nenhum. A Arte deve se erguer acima dos afetos pessoais e suscetibilidades excitáveis. Está na hora de dar a ela a perfeição das ciências físicas, através de um método que seja impiedoso." E mais adiante, "Eu sempre busquei não diminuir a Arte para satisfazer alguma personalidade isolada." Ele estava se referindo principalmente a arte da literatura; mas se ele sente isso de maneira tão forte sobre o escritor, uma pessoa que nunca é vista e apenas se mostra parcialmente por trás de sua arte, como se colocaria totalmente em oposição à atual figura do ator - personalidade ou não personalidade.

Charles Lamb disse: "Quando se vê uma representação de Lear, um velho trôpego com um bastão, colocado porta afora numa noite chuvosa pelas duas filhas, esta cena não remete a nada que não seja doloroso e repugnante. Desejamos levá-lo a algum abrigo, este é o sentimento que a representação de Lear sempre causou em mim. A desprezível maquinaria com que imitam a tempestade na qual ele adentra é tão inadequada em representar o horror dos elementos naturais quanto qualquer ator em representar o próprio Lear. Seria mais fácil propor encarnar o Satã de Milton sobre o palco, ou uma das terríveis figuras de Michelangelo. O rei Lear é, em sua essência, impossível de ser representado sobre o palco." 
“O próprio Hamlet parece quase impossível de ser representado," disse William Hazlitt.

Dante em La Vita Nuova nos conta que, em sonho, o Amor, na figura de um jovem, apareceu a ele. Conversando sobre Beatrice, o Amor diz a Dante "para compor alguma coisa em versos, nos quais deixe claro o quão forte é o domínio que, por causa dela, eu obtive sobre vós. Escreva essas coisas de tal forma que pareçam mais apropriadas se ditas por uma terceira pessoa, e não diretamente por vós a ela, o que não seria muito adequado." E ainda: "Se surge em mim um enorme desejo de dizer algo em versos, quando eu começo a pensar em como deveria fazê-lo, me parece que falar sobre ela não seria próprio, a menos que eu falasse a outras mulheres na segunda pessoa." Vemos então que para estes homens não é certo que uma pessoa se coloque em uma moldura e exponha a si mesma em sua própria tela. Eles julgam "impróprio" e "inadequado"

Temos aqui testemunhas contra toda essa empresa chamada teatro moderno. Coletivamente, eles dão a seguinte sentença: É arte de má qualidade ser tão pessoal, tão emotivo, em um apelo para que o espectador esqueça-se da coisa em si e seja afogado pela personalidade, pela emoção, daquele que atua. E agora, um testemunho de uma atriz.

Eleonora Duse disse: "Para salvar o Teatro, o teatro precisa ser destruído, os atores e atrizes devem todos morrer de peste. Eles envenenam o ar, eles fazem a arte impossível. ${ }^{3}$

Podemos acreditar em suas palavras. Ela quer dizer o mesmo que Flaubert e Dante, ainda que as palavras sejam diferentes. E existiriam ainda muitos mais testemunhos a meu favor se, por acaso, estas evidências não fossem suficientes. Algumas pessoas nunca vão ao teatro, são milhões de homens contra apenas algumas milhares dos que realmente vão. Além disso, temos o apoio da maioria dos diretores das peças de hoje. Os diretores de peças modernos pensam que uma peça sobre o palco deve ser sempre decorada de forma exuberante. Ele afirma que não devem ser medidos esforços na criação da circunstância onde o público possa ser iludido com uma sensação de realidade. Ele nunca cessa de nos afirmar como toda essa decoração é importante. Ele insiste nisso por várias razões, a principal delas é a seguinte: ele sente um grande perigo em um trabalho que seja simples e bom. Ele percebe que existe um grupo de pessoas que se opõem a essas excessivas decorações e que existe um movimento nítido na Europa contra esse tipo de ostentação, que afirma que as grandes peças crescem quando representadas sobre um fundo limpo. Este movimento é comprovadamente forte, se espalhou de Cracóvia a Moscou, de Paris a Roma, de

${ }^{3}$ Studies in Seven Arts. Arthur Symons (Constable, 1900). (N. do A.) 
Londres a Berlim e Viena. Os diretores veem este perigo a sua frente; eles imaginam que uma vez que o público se dê conta deste fato, que a audiência prove do encanto que uma peça sem cenários pode trazer, eles irão em seguida mais adiante e pedir uma peça sem atores, e finalmente podem ir ainda mais longe, e cada vez mais, até que, por fim, os espectadores, e não os diretores, realizem a devida reforma da arte.

Napoleão supostamente teria dito: "Na vida há muito de coisas indignas que as artes devem por bem omitir, muito de dúvida e hesitação, e tudo isso deveria desaparecer na representação de um herói. Devemos vê-lo como uma estátua na qual toda fraqueza e os tremores da carne não sejam mais perceptíveis." E não só Napoleão, mas Ben Jonson, Lessing, Edmund Coleridge, Anatole France, Ruskin, Pater ${ }^{4}$, e suponho todos os homens e mulheres inteligentes da Europa - não falemos da Ásia, pois mesmo aquele que é inculto na Ásia não consegue admitir a fotografia, ao mesmo tempo que compreende a arte como uma manifestação simples e clara - tem protestado contra essa reprodução da natureza e com ela a realidade fotográfica e frágil. Eles têm protestado contra tudo isto, e os diretores teatrais retrucam energicamente. Esperemos então que a verdade apareça no devido tempo. É uma conclusão razoável. Excluam a árvore real, excluam a realidade da expressão, excluam a realidade da ação, e se caminhará para a exclusão do ator. Isto é o que irá acontecer algum dia, e gosto de ver alguns diretores apoiando desde já esta idéia. Excluam o ator e excluirão os meios pelos quais esse aviltante realismo de palco é produzido e floresce. Não mais se terá a figura humana para nos confundir conectando a realidade e a arte. Não mais a figura viva, na qual as fraquezas e tremores da carne são tão perceptíveis. $O$ ator deve sair e em seu lugar surgir a figura inanimada, a Supermarionete, podemos chamá-la assim, até que tenha conquistado para si um nome melhor. Muito se tem escrito sobre bonecos, ou marionetes, e alguns excelentes livros foram escritos sobre eles. Várias obras de arte foram inspiradas por eles. Atualmente, nesses tempos menos felizes, muitas pessoas acabam por olhá-los mais como uma boneca de status superior, e pensam que ele se originou a partir de uma boneca, um brinquedo. Isso é incorreto.

\footnotetext{
${ }^{4}$ Sobre escultura, Pater escreve: "Sua luz branca, purificada das raivosas e sangrentas manchas da ação e da paixão, revela, não o acidental, mas o divino no homem, se opondo à incessante agitação humana." E ainda: "A base para toda criação artística é o poder de conceber a humanidade de uma maneira nova, admirável e feliz, substituindo o mundo mesquinho do cotidiano por um mundo cheio de júbilo, feito pela mão do artista; fazendo surgir em torno a si uma atmosfera com um novo poder de refração, selecionando, transformando e recombinando as imagens que transmite, de acordo com a escolha do intelecto imaginativo." E mais adiante: "Tudo o que é acidental, tudo o que perturba o efeito mais simples sobre nós dos elevados tipos de humanidade, todos os traços de vulgaridade do mundo, é lentamente eliminado." (N. do A.)
} 
A marionete é uma descendente das imagens de pedra de antigos templos. Hoje ela é a forma degenerada de um deus. Sempre amigo íntimo de crianças, ela ainda sabe muito bem como selecionar e atrair seus devotos.

Quando alguém desenha uma marionete em um papel, ele rabisca uma coisa rija e desengonçada. Esta pessoa nem sequer percebe o que está contido nesta idéia que hoje chamamos de marionete. Ele não se dá conta da gravidade das feições e a calma do corpo, e julga se tratar de simples deformidades angulosas e estupidez. Mesmo as marionetes modernas são extraordinárias. Podem chover aplausos, ou somente gotejar: seus corações não disparam, nem ralentam, seus gestos não se exasperam ou desordenam; ou ainda se coberta de flores e elogios, a protagonista mantém seu rosto solene, belo e distante como sempre. Existe algo além de um lampejo genial na marionete, algo mais nela que um simples brilho de uma personalidade em exposição. A marionete me parece o último eco de alguma arte nobre e bela de uma civilização antiga. Mas, como todas as artes, acabou caindo em mãos grosseiras ou incultas e o boneco, a marionete, se tornou uma vergonha. Todos os bonecos atualmente não passam de comediantes vulgares.

Eles imitam a pior e mais genuína raça de atores do teatro. Entram em cena apenas para cair de traseiro no chão. Bebem apenas para cambalear e fazem amor somente para arrancar risadas. Esqueceram-se completamente dos conselhos de sua mãe, a esfinge. Seus corpos perderam a graça e se tornaram rijos. Seus olhos perderam aquela sutileza infinita de parecer realmente enxergar. Agora, apenas olham fixamente o vazio. Eles exibem e balançam seus fios e se movem arrogantes em sua sabedoria de madeira. Erram ao se esquecerem que sua arte deve trazer em si o selo da discrição que vemos por vezes no trabalho de outros artistas, e que a arte mais elevada é aquela que oculta o ofício e faz esquecer o artífice. Um antigo viajante, no ano de 800 a.C., ao descrever sua visita ao Templo-teatro de Tebas nos conta que foi conquistado pelas belezas de suas "nobres artificialidades". "Entrando na Casa de Visões, eu vi ao longe uma bela Rainha morena sentada em seu trono, ou sua tumba - poderia ser uma coisa ou outra. Eu recostei em meu divã e me pus a admirar seus movimentos simbólicos. Com que suavidade os ritmos se alteravam enquanto seus movimentos alternavam entre um membro e outro. Com que demonstração de tranqüilidade ela revelou a nós os pensamentos que lhe iam por dentro. A gravidade e a beleza com que ela se deixava estar em seu sentimento de tristeza, parecia nos dizer que nenhuma dor jamais poderia magoá-la. 
Nenhuma alteração em seu corpo ou feições permitia que pudéssemos sequer sonhar que estivesse sendo subjugada. A paixão e a dor, ela as tomava em suas mãos, uma após a outra, ela as retinha gentilmente e as observava com calma. Seus braços e mãos pareceram a um momento como uma fina e tépida fonte de água que surge e depois se dobra e escorre com todos os seus longos e pálidos dedos como espuma em direção a seu colo. Teria sido como uma revelação da arte para nós, não tivesse eu já visto o mesmo espírito abrigado em outros exemplos de arte dos egípcios. Esta Arte de Velar e Revelar', como eles a chamam, é uma força espiritual tão grande nesta terra que ocupa uma parte preponderante de sua religião. Podemos aprender algo sobre o poder e a graça da coragem, pois é impossível assistir tal performance sem uma sensação de repouso físico e espiritual." Isto aconteceu em 800 a.C. Quem sabe talvez o boneco, a marionete, possa voltar a ser o agente fidedigno para os propósitos de beleza do artista? Poderíamos então olhar em frente com a esperança do dia em que se trará de volta a figura, ou criatura simbólica, construída também pela habilidade do artista, para que tenhamos uma vez mais a "nobre artificialidade" da qual falavam os antigos escritores. $E$ que assim não mais nos submetamos à cruel influência de emotivas confissões de fraqueza que todas as noites são testemunhadas pelo público e que, por sua vez, criam naqueles que assistem a mesma fraqueza que é exibida no palco. Para isso precisamos estudar para refazer estas imagens, não mais simplesmente bonecos, precisamos criar uma Supermarionete. A Supermarionete não competirá com a vida, ela irá além dela. Seu ideal não será o carne e osso, mas o corpo em êxtase. Ele buscará se vestir com uma beleza mortuária e ao mesmo tempo exalar um espírito vivo. Muitas vezes durante esse ensaio, uma palavra ou duas sobre a Morte surgiu no papel, convocada ali pelo incessante clamor de "Vida! Vida! Vida!" que os realistas mantêm. E isto poderia ser facilmente entendido como presunção, especialmente por aqueles que não possuem simpatia ou prazer no poder e na misteriosa alegria presente em toda e qualquer obra de arte realizada livre da emoção. Se o renomado Rubens e o célebre Rafael realizaram apenas obras exuberantes e apaixonadas, por outro lado existiram vários outros artistas antes e depois destes a quem, ao contrário, o comedimento era o mais precioso de todos os seus objetivos, e estes, mais do que todos os outros, exibiram uma qualidade verdadeiramente viril. Os outros, extravagantes ou lânguidos, são artistas cujos nomes e obras, à luz de nossos tempos, não nos falam devidamente como homens, apenas berram como animais ou ceceiam como mulheres. 
Os sábios, os moderados mestres, sólidos por causa das leis às quais juraram permanecer fiéis - uma dinastia admirável, ainda que seus nomes sejam desconhecidos para a maioria -, os criadores de grandes e minúsculos deuses do Oriente e do Ocidente, guardiões de tempos memoráveis, todos eles dirigem seus pensamentos para frente, em direção ao desconhecido, procurando por visões e sons naquele país tranqüilo e feliz, onde eles erguerão uma figura de pedra ou entoarão um verso, investidos daquela mesma paz e alegria vislumbrada de longe, contrabalançando todas as tristezas e perturbações encontradas aqui.

$\mathrm{Na}$ América podemos imaginar estes irmãos dessa família de mestres, vivendo em suas soberbas cidades antigas, cidades colossais, que eu sempre pensei ser possível movê-las em um único dia, cidades feitas de enormes tendas de seda e dourados dosséis sob os quais moram seus deuses, moradas que possuem tudo o que é preciso para agradar aos mais exigentes. Estas cidades nômades ao se deslocarem de montanhas a planícies, do alto dos rios ou ao longo de seus vales, pareceriam um vasto exército de paz, em marcha. E em cada uma destas cidades não se teria apenas um ou dois homens chamados "artistas" a quem todo o resto da cidade rotula como vagabundos irresponsáveis, mas muitos homens escolhidos pela comunidade justamente por causa de sua elevada capacidade de percepção: artistas. Pois isso é o que o título de artista quer dizer: aquele que percebe mais que seus colegas, e que registra mais do que aquilo que pode ser visto. E não em menor nível entre os artistas se encontra aquele artista cerimonial, o criador de visões, o sacerdote cujo dever é celebrar seu espírito orientador, o espírito do Movimento.

$\mathrm{Na}$ Ásia também os mestres esquecidos dos templos, e tudo o que aqueles templos contêm, permearam cada pensamento, cada sinal presentes em suas obras com esse sentido de tranquila movimentação assemelhada à morte, glorificando-a e celebrando-a. Na África (que alguns de nós pensam que estamos ainda por civilizar) este espírito vive, a essência da civilização perfeita. Lá também, moram os grandes mestres, sem obsessões individuais com a idéia de afirmar sua personalidade como se fosse uma coisa poderosa e de muito valor, mas contentes por um tipo de paciência sagrada em mover seus cérebros e seus dedos somente naquela direção permitida pelas leis - a serviço das verdades simples.

Ao se observar qualquer exemplo da arte egípcia, pode-se identificar quão rígida era esta lei e como tão pouco os artistas daquele tempo se permitiam exibir seus 
sentimentos pessoais. Olhe para cada membro esculpido pelos egípcios, procure em todos aqueles olhos esculpidos e eles se negarão a você até o final dos tempos. Sua atitude é tão silenciosa que se assemelha à morte. Ainda assim, a ternura está ali, assim como o encanto. A beleza também está, lado a lado com a força. E o amor, banhando a cada trabalho. Mas arroubo, emoção, afirmação arrogante de personalidade do autor? Nem um traço sequer. Dúvidas ferozes sobre o futuro? Nem um pouco. Determinação obstinada? Nem um sinal esse artista deixa escapar. Nenhuma dessas confissões, estupidezes. Nem orgulho, nem temor, nem o cômico, nem nenhuma indicação de que a mente do artista ou suas mãos estejam nem a milésima parte de um momento fora do controle das leis que comandam suas ações. Quão soberbo! Isto é o que é um grande artista, e a quantidade de emoções efusivas de hoje e de ontem não são sinais de inteligência em alto grau, o que vale dizer, que não são sinais tampouco de arte em alto grau. À Europa veio este espírito, pairou sobre a Grécia, foi expulsa com dificuldade da Itália, até finalmente desaparecer, deixando um pequeno rastro de lágrimas, pérolas, diante de nós. E nós, tendo esmagado a maioria delas, mastigando-as entre nosso bolo de comida, fomos mais longe e pior, e nos prostramos diante dos chamados "grandes mestres", e temos adorado essas personalidades perigosas e extravagantes. Em um dia infeliz, pensamos, em nossa ignorância, que eles haviam sido enviados para nos desenhar, que haviam sido enviados para expressar os nossos pensamentos, que tinham algo a ver conosco, a arquitetura e a música que nos apresentavam. Foi assim que passamos a pedir que fossemos capazes de nos reconhecer em tudo o que mostravam, ou seja, em sua arquitetura, em sua escultura, em sua música, em sua pintura, e na poesia feita para representar - e ainda hoje os lembramos de nos convidar com as palavras usuais: "Venham, assim como são".

Depois de muitos séculos, os artistas cederam e o que pedimos a eles, eles nos deram. E aconteceu que quando nossa ignorância expulsou o espírito justo que um dia havia controlado a mente e a mão do artista, um espírito tenebroso tomou seu lugar. Um vândalo despreocupado no lugar da lei, ou seja, um espírito estúpido no lugar do rei. E todos começam a gritar por Renascimento! Enquanto isso, pintores, músicos, escultores, arquitetos, competem entre si para suprir a demanda, para que todos esses produtos possam ser feitos de tal maneira que todas as pessoas consigam reconhecer nelas algo de si mesmas.

Brotaram estes retratos com faces ruborizadas, olhos protuberantes, bocas contorcidas, dedos ansiosos em fugir da moldura, pulsos expondo suas pulsações, todas as 
cores em desordem total, todas as linhas em tumulto, como os desvarios da insanidade. As formas se contorcem em pânico, o sopro calmo e fresco da vida em transe que um dia insuflou uma esperança indescritível, se enfureceu, queimou em uma labareda e foi destruído. Em seu lugar: realismo, esta obtusa afirmação de vida, esse grande mal-entendido, no qual todos se reconhecem. Absolutamente afastado do objetivo da Arte, seu propósito não é refletir a realidade dos fatos dessa vida, uma vez que não é do comportamento do artista andar atrás das coisas, pois conquistou o privilégio de caminhar à frente delas, de liderar. A vida deveria, antes, refletir a semelhança com o espírito, pois foi o espírito quem a princípio escolheu o artista para narrar suas belezas ${ }^{5}$. E nesta imagem, se as formas acompanham aquelas dos seres vivos, por sua beleza e ternura, suas cores precisam ser buscadas no desconhecido território da imaginação; e o que seria isso senão o território onde mora aquilo que chamamos de Morte? Portanto não é leviano ou petulante que eu fale sobre bonecos, marionetes, e sua capacidade de preservar as belas e distantes expressões na forma e na face mesmo quando submetidas aos louvores de uma torrente de aplausos. Algumas pessoas zombam desses bonecos. "Boneco" é um termo utilizado atualmente com desdém, mas existem aqueles que ainda encontram beleza nessas pequenas figuras, degeneradas assim como se tornaram.

Falar sobre bonecos, marionetes, com a maioria dos homens e mulheres é motivo para risadas. Pensam imediatamente em fios, pensam em mãos rígidas e movimentos desengonçados, e me dizem: "é apenas um brinquedinho engraçado". Mas permitam-

\footnotetext{
5 "Todas as formas são perfeitas na mente do poeta: mas não as extrai nem as compõem a partir da Natureza; elas vêm da Imaginação." - William Blake (N. do A.)
}

\section{Notas de tradução:}

1. Estas, acima, são as únicas notas de autor presentes na edição de janeiro de 1912 de On the Art of the Theatre, de Edward Gordon Craig.

2. Nesta tradução estão incluídos alguns trechos omitidos na edição portuguesa, com tradução de Redondo Junior, realizada na década de 1960. Além disso, alguns outros trechos sofreram recortes e sínteses que desconfiguram, senão o sentido central, seguramente a forma - o que acaba alterando também, de alguma maneira, o primeiro. A lacuna principal é um grande trecho onde Craig fala sobre a relação entre a Morte e a inspiração do artista. Várias outras pequenas lacunas se repetem na tradução portuguesa, entre elas as que Craig se refere, de maneira qualificativa, à relação entre as mulheres e a arte. Foi evitado, nesta tradução, qualquer tipo de resumo para que se mantivesse, o mais possível, a forma original, com suas repetições propositais de palavras e trechos, bem como sua verve por vezes em espiral. Recursos formais que embebem o texto de Gordon Craig de qualidades indissociáveis de seu conteúdo, como o caráter essencialmente didático, um sentimento profundamente poético e as nuances de um humor fino e particular.

3. O termo "puppet" (literalmente "boneco", que em inglês abrange todo tipo de bonecos: fantoches, marionetes, bonecos de vara, formas animadas, etc.) é utilizado por Craig em todo o texto e propôs uma dificuldade para a precisão na tradução. Buscou-se, caso a caso, uma conversão que melhor se adequasse a cada situação específica. 
me falar-Ihes algumas coisas sobre esses bonecos. Permitam-me repetir uma vez mais que eles são descendentes de uma grande e nobre família de imagens, imagens feitas, de fato, "à semelhança de Deus." E que muitos séculos atrás essas figuras tinham um movimento rítmico e não desengonçado, não havia necessidade de fios para sustentálos, nem falavam com a voz nasalada de um manipulador oculto. [Pobre Punch, não pretendo menosprezá-lo! Você está sozinho, dignificado em seu desespero, enquanto olha para séculos passados com seus olhos pintados ainda molhados pelas lágrimas em seu rosto tão antigo, e você parece gritar suplicante por seu cão: "Irmã Anne, irmã Anne, não vem ninguém?" Depois com aquela sua bravata excelente, você direcionou nossos risos (e minhas lágrimas) sobre si mesmo com seus gritos pungentes: "Oh, meu nariz! Oh, meu nariz! Oh, meu nariz!'] Vocês creem, senhoras e senhores, que esses bonecos foram sempre pequenas coisas de 30 centímetros de altura?

De fato, não! Os bonecos já foram um dia uma figura mais nobre do que vocês mesmos.

Pensam que ele esteve sempre a saltitar perambulando sobre uma pequena plataforma de cerca de dois metros quadrados, construída para lembrar um pequeno teatro antigo, onde sua cabeça quase toca o teto do proscênio? Acreditam que ele sempre viveu em uma pequena casa onde a porta e as janelas são pequenas como as de uma casa de bonecas, pintadas e abertas de par em par, onde as flores de sua jardineira exibem pétalas do tamanho de sua cabeça? Tentem abandonar essas idéias de uma vez por todas e deixem-me dizer uma coisa sobre sua verdadeira casa.

A Ásia foi seu primeiro reino. Às margens do Ganges eles construíram sua casa, um imenso palácio que se erguia de uma coluna a outra em direção aos céus e vertiam de coluna em coluna novamente para dentro das águas. Cercado de imensos jardins, quentes e abundantes em flores e refrescados por fontes, jardins nos quais som algum penetrava e no qual raramente algo se agitava. Apenas no interior dos frescos e reservados aposentos de seu palácio, as mentes aguçadas de seus seguidores moviam-se incessantemente. Preparavam algo que fizesse jus a ele, algo que homenageasse o espírito que Ihes havia trazido à vida. E então, um dia, a cerimônia.

Nesta cerimônia, ele tomou parte, uma celebração novamente em homenagem à Criação; a antiga Ação de Graças, o viva à existência, e com um viva mais vigoroso ao privilégio da existência porvir, que é velada pela palavra Morte. E durante esta cerimônia surgiam diante dos olhos de seus devotos morenos os símbolos de todas as coisas na terra e no Nirvana. O símbolo da árvore bela, o símbolo das montanhas, 
os símbolos de todos os ricos minérios que as montanhas abrigam, os símbolos da nuvem, do vento, e de todas as coisas ágeis, o símbolo do mais rápido dentre tudo o que se move, do pensamento, da recordação; o símbolo do animal, o símbolo de Buda e do Homem, e eis que ela surge, a figura, a marionete, o boneco, do qual todos tanto riram. Riem dele hoje, pois nada lhe restou a não ser, as suas fraquezas. As fraquezas que são, em verdade, apenas nosso reflexo. Mas, não teriam rido se o tivessem visto em seu auge, na época em que ele era convocado a ser o símbolo do ser humano em uma grande cerimônia e, ainda mais, era em si a imagem do encanto que tomava conta de nosso próprio coração. Se rimos e insultamos a memória desses bonecos, deveríamos antes, rir da ruína que causamos a nós mesmos, rir de todas as crenças e das imagens que quebramos em nós. Alguns séculos mais tarde encontramos a sua casa deteriorada. De um templo, ela se tornou, não diria um teatro, mas algo entre um teatro e um templo, onde ele perde sua vitalidade. Algo paira no ar e os seus médicos Ihe recomendam ser cuidadoso. "E a quê eu deveria mais temer?" ele lhes pergunta. Eles Ihe respondem: "Tema acima de tudo a vaidade dos homens." Ele pensa: "Mas é exatamente isto o que eu tenho ensinado ao longo de todo o tempo: que nós, que celebramos com alegria esta existência, devemos cultivar, mais que tudo, esse grande temor. É possível que logo eu, aquele que sempre revelou a verdade, deve ser aquele que perde isto de vista e que seja o primeiro a decair? Está claro que algum ataque sutil se abate sobre mim. Manterei meus olhos nos céus." Ele despede seus médicos e se põe a meditar sobre o assunto.

Agora permitam que eu conte quem foi o responsável por perturbar a atmosfera serena que circundava esse ser curiosamente perfeito. Os registros relatam que, algum tempo mais tarde, ele resolveu estabelecer sua morada na costa do Extremo Oriente e vieram duas mulheres contemplá-lo. E nesta cerimônia que presenciaram, ele brilhou com tal esplendor terreno e tal sobrenatural simplicidade, que causou uma profunda inspiração a mil novecentas e noventa e oito pessoas que participavam do festival, uma inspiração que clareou a mente de todos ao mesmo tempo em que as intoxicava. Apenas duas mulheres, entre todas, experimentaram somente a intoxicação. Ele não as viu, seus olhos estavam fixos nos céus. Assim mesmo, as encheu de um desejo grande demais para ser sufocado, o desejo de se tornar o símbolo direto da divindade nos homens. $\mathrm{E}$ sem muita demora vestiram-se o melhor que puderam ("dessa maneira", pensaram), movendo-se com gestos ("dessa maneira", disseram) e capazes de causar um encanta- 
mento nas mentes dos devotos ("da maneira que ele faz", exclamaram), construíram para si um templo ("dessa maneira, dessa maneira!"), e satisfizeram as demandas do povo, tornando a coisa inteira uma paródia pobre e lamentável.

Assim está registrado. É o primeiro registro no Oriente sobre o ator. O ator surgiu da tola vaidade de duas mulheres que não foram fortes o suficiente para contemplar o símbolo da divindade sem desejar falsificá-lo, e a paródia se mostrou bastante lucrativa. Em cinqüenta ou cem anos, lugares para tais paródias podiam ser encontrados por toda a região.

Ervas - daninhas, dizem, crescem rapidamente, e essa selva de ervas - daninhas chamada teatro moderno, rapidamente se espalhou. A figura do boneco, da marionete divina, atraía cada vez menos adoradores, e as mulheres se tornaram a grande novidade. Com o desaparecimento gradual do boneco e o crescimento das mulheres que se exibiam em um palco em seu lugar, veio aquele espírito obscuro ao qual chamamos de Caos, e em seu despertar o triunfo da personalidade degradada. Você entende, então, o que me fez amar e aprender o valor do que chamamos hoje de "marionete" e detestar o que chamamos "vida" na arte? Eu rezo fervorosamente pelo retorno da imagem, da Supermarionete, ao Teatro. E quando ela surgir e for vista, ela será adorada tanto que uma vez mais será possível para as pessoas recuperarem a antiga alegria das cerimônias. Uma vez mais a Criação será celebrada, homenagens rendidas à existência e intercessões divinas e felizes serão feitas à Morte. 